\title{
Analisis Kesalahan Siswa dalam Menyelesaikan Soal Kontekstual pada Materi Bangun Ruang Sisi Datar Ditinjau dari Teori Nolting
}

\author{
Fitria Ulpa ${ }^{*}$, Shaffarina Anindia Maharani, Salma Marifah, Nani Ratnaningsih \\ Universitas Siliwangi \\ *fitriaulpa14@gmail.com
}

\begin{abstract}
ABSTRAK
Penelitian ini bertujuan untuk mendeskripsikan serta menganalisis jenis-jenis kesalahan yang dilakukan oleh siswa dalam menyelesaikan soal kontekstual pada materi bangun ruang sisi datar dan mengetahui faktor penyebabnya. Jenis penelitian yang dilakukan yaitu penelitian deskriptif kualitatif. Penelitian dilakukan di SMP Al-Ahyar Sukaratu, dengan mengambil subjek kelas VIII A sebanyak 9 orang. Instrumen yang digunakan dalam penelitian adalah soal tes kontekstual matematika berupa 3 soal esai. Teknik pengumpulan data berasal dari hasil jawaban tes tulis dan hasil wawancara siswa. Analisis data dilakukan secara kualitatif, dengan langkah-langkahnya yaitu kondensasi data, penyajian data dan penarikan kesimpulan. Hasil dari penelitian ini dapat dijadikan sebagai upaya meningkatkan kemampuan siswa dalam pemecahan masalah kontekstual pada materi bangun ruang sisi datar. Berdasarkan hasil penelitian, diperoleh informasi bahwa terdapat 6 jenis kesalahan siswa dalam menyelesaikan soal kontekstual berdasarkan Teori Nolting, dengan persentase untuk setiap jenis kesalahan yaitu kesalahan membaca petunjuk $40,74 \%$, kesalahan kecerobohan $44,44 \%$, kesalahan konsep $29,62 \%$, kesalahan penerapan 37,03\%, kesalahan saat tes $77,77 \%$, dan kesalahan belajar 44,44\%. Secara umum, faktor penyebab siswa melakukan kesalahan yaitu siswa jarang mengerjakan latihan soal kontekstual, siswa lebih menekankan hafalan rumus daripada pemahaman konsep serta siswa kurang memperdalam materi. Solusi untuk mengatasi hal tersebut, yaitu sering melakukan latihan soal yang bersifat kontekstual, memahami konsep materi yang diajarkan dari berbagai sumber terpercaya.
\end{abstract}

Kata kunci: kesalahan siswa, soal kontekstual, bangun ruang sisi datar, Teori Nolting.

\section{ABSTRACT}

This study aims to describe and analyze the types of errors made by students in solving contextual problems on the polyhedron material and knowing the causes. The type of research conducted is descriptive qualitative research. The study was conducted at SMP Al-Ahyar Sukaratu, taking the subject of class VIII A as many as 9 people. The instrument used in the study was a contextual mathematics test in the form of 3 essay questions. The data collection technique came from the results of the written test answers and the results of student interviews. Data analysis was carried out qualitatively, with the steps being data condentation, data presentation and making a conclusions. The results of this study can be used as an effort to improve students' ability in solving contextual problems in the material of polyhedron. Based on the results of the study, information was obtained that there were 6 types of student errors in solving contextual problems based on the Nolting theory, with the percentage for each type of error, namely reading instructions errors $40.74 \%$, carelessness errors $44.44 \%$, conceptual errors $29.62 \%$, errors application of $37.03 \%$, errors during the test $77.77 \%$, and learning errors of $44.44 \%$. In general, the factors that cause students to make mistakes are that students rarely do contextual practice questions, students emphasize memorizing formulas more than understanding concepts and students do not deepen the material. The solution to overcome the problem is by often doing contextual practice questions, understanding the concept that has been taught from various reliable resources.

Keywords: student error, contextual problem, polyhedron, nolting theory. 


\section{PENDAHULUAN}

Matematika adalah salah satu bidang studi yang harus dikuasai oleh siswa, karena merupakan sarana pemecahan masalah sehari-hari. Hal tersebut sejalan dengan pendapat (Hasibuan, 2018) bahwa pendidikan matematika memiliki peranan penting dalam kehidupan sehari-hari, melalui pendidikan matematika siswa diharapkan dapat menjadi manusia yang mampu untuk berpikir logis, kritis, teliti, kreatif, inovatif, kerja keras serta optimis. Dengan adanya pemecahan masalah pada kehidupan sehari-hari, siswa dituntut untuk bisa berpikir lebih konkret lagi. Namun pada kenyataannya, siswa belum mampu mengimplementasikan ilmu matematika yang ia miliki secara utuh untuk pemecahan masalah yang terjadi dalam kehidupan sehari-hari. Hartika (Oktafia \& Sutama, 2019) menyatakan bahwa dalam penerapan pembelajaran matematika tidak sedikit siswa yang mengalami kesulitan untuk memahami soal. Kesulitan tersebut berdampak pada rendahnya prestasi siswa.

Kesulitan siswa memungkinkan terjadinya kesalahan dalam menyelesaikan soal pada materi tertentu. Menurut Rosyidi (Fazzilah et al., 2020) kesalahan adalah sebuah bentuk penyimpangan terhadap hal yang telah dianggap benar berdasarkan prosedur yang ditetapkan sebelumnya. Rindiyana (Prihatin \& Setiawan, 2020) mengemukakan bahwa kesulitan dan kesalahan yang paling banyak dialami siswa dalam menyelesaikan masalah kontekstual adalah rendahnya keterampilan berpikir kritis siswa dalam menyelesaikan pemecahan masalah kontekstual. Berdasarkan hasil wawancara dengan beberapa guru matematika SMP, bahwa dalam menyelesaikan soal matematika terutama pokok bahasan bangun ruang sisi datar masih banyak siswa yang mengalami kesulitan, sehingga menyebabkan kesalahan dalam menyelesaikan soal. Kesalahan biasanya terjadi karena tingkat pemahaman konsep siswa tentang materi tersebut masih rendah sehingga siswa sulit untuk mengingat materi yang sudah disampaikan oleh guru.

Permasalahan kontekstual umumnya disajikan dalam bentuk soal cerita. Soal kontekstual matematika adalah soal-soal yang menggunakan berbagai konteks sehingga menghadirkan sesuatu yang pernah dialami oleh siswa. Salah satu materi yang dekat dengan kehidupan seharihari siswa adalah bangun ruang sisi datar. Bangun ruang sisi datar merupakan salah satu materi yang umumnya disajikan dalam bentuk soal cerita yang kontekstual. Banyak siswa kesulitan dalam menyelesaikan soal pada materi ini, yang berakibat siswa melakukan kesalahan dalam menyelesaikan soal. Hal tersebut dikarenakan siswa kurang berlatih mengerjakan soal-soal, siswa juga melakukan kesalahan seperti tidak membaca soal dan kurang memahami konsep, hal ini sejalan dengan penelitian yang dilakukan oleh (Fajriyati Afdila et al., 2018) mengenai Analisis Kesalahan Siswa dalam Menyelesaikan Masalah Kontekstual Materi Bangun Ruang Sisi Datar Berdasarkan Tahapan Kastolan. Hasil penelitian tersebut mengungkapkan bahwa dalam penyelesaian ketiga soal yang diberikan, banyak siswa yang melakukan kesalahankesalahan seperti kesalahan konseptual, prosedural, dan teknikal. Sedangkan faktor-faktor penyebab siswa melakukan kesalahan yaitu siswa kurang cermat membaca dan memahami maksud soal dengan baik, siswa hanya menghafal rumus dan belum memahami konsep dengan baik, dan siswa kurang teliti dalam pengerjaan soal. Terdapat pula penelitian yang dilakukan oleh (Prihatin \& Setiawan, 2020) tentang analisis kesalahan siswa SMP kelas IX dalam menyelesaikan soal pada materi pokok bangun ruang sisi datar, kesimpulan dari hasil penelitian tersebut yaitu; (1) siswa kurang teliti dalam membaca dan memahami maksud soal, (2) siswa 
hanya menghafal rumus belum memahami konsep dengan baik, (3) siswa kurang teliti dalam pengerjaan soal. Hasil-hasil penelitian tersebut berbeda dengan yang peneliti akan laksanakan dan penelitian tersebut belum mampu memberikan alternatif solusi sehingga penelitian ini masih layak untuk dilaksanakan.

Analisis kesalahan merupakan salah satu strategi yang dapat digunakan untuk memperbaiki kesalahan siswa dalam mengerjakan soal. Menurut Rushton (Napfiah \& Sulistyorini, 2021) analisis kesalahan adalah langkah efektif dalam mengatasi kesalahpahaman dan memungkinkan siswa untuk merefleksikan pembelajaran mereka. Selain bermanfaat untuk siswa, analisis kesalahan juga memberikan manfaat bagi guru. Melalui analisis kesalahan, guru memiliki pengetahuan terhadap letak dan jenis kesalahan siswa. Dengan demikian, guru dapat menindaklanjuti dengan menyusun strategi, model, dan media pembelajaran yang tepat guna mengurangi kesalahan siswa. Sejalan dengan yang diungkapkan Sapire (Napfiah \& Sulistyorini, 2021) bahwa analisis kesalahan merupakan bagian yang tidak terpisahkan dari ilmu pengetahuan yang dimiliki oleh guru, maksudnya bagaimana guru mengambil tindakan terkait kesalahan siswa dan tergantung pada seberapa dalam pengetahuan dan konsep guru yang terkait dengan kesalahan tersebut.

Metode analisis kesalahan siswa yang digunakan dalam penelitian ini adalah metode analisis Teori Nolting. Menurut Dr. Paul Nolting (Nolting, 2012) jenis kesalahan peserta didik dalam mengerjakan tes terdapat 6 jenis, yaitu Kesalahan Petunjuk Arah (Misread-Directions Errors), yang merupakan kesalahan yang terjadi karena siswa melewatkan petunjuk arah atau salah memahami petunjuk arah tetapi melakukan kesalahan pula. Kesalahan Ceroboh (Careless Errors), yaitu kesalahan yang disebabkan oleh kecerobohan peserta didik. Kesalahan Konsep (Concept Errors), adalah kesalahan yang dilakukan ketika peserta didik tidak memahami konsep dan prinsip matematika yang digunakan untuk menyelesaikan soal. Kesalahan Penerapan (Application Errors), yaitu kesalahan yang dilakukan ketika peserta didik mengetahui rumus tetapi tidak dapat menerapkannya untuk menyelesaikan soal. Kesalahan Saat Tes (Test Taking Errors), yaitu kesalahan yang ditimbulkan hal-hal khusus misalnya tidak menyelesaikan jawaban dari soal yang diberikan. Serta kesalahan belajar (Study Errors), yaitu kesalahan yang terjadi ketika siswa mempelajari jenis materi yang salah atau tidak menghabiskan cukup waktu untuk mempelajarinya.

Berdasarkan pengklasifikasian tersebut, terlihat jelas bahwa metode analisis kesalahan Teori Nolting ini lebih menekankan pada analisis kesalahan konsep. Meninjau kesalahan konsep dapat meningkatkan pemahaman tentang matematika. Kesalahan konsep harus diperbaiki untuk meningkatkan prestasi belajar selanjutnya. Siswa yang banyak melakukan kesalahan konsep akan gagal dalam menyelesaikan soal-soal matematika. Oleh karena itu, penulis memutuskan untuk menggunakan Teori Nolting sebagai metode analisis kesalahan.

Berdasarkan uraian di atas, peneliti melakukan penelitian dengan judul "Analisis Kesalahan Siswa dalam Menyelesaikan Soal Kontekstual pada Materi Bangun Ruang Sisi Datar Ditinjau dari Teori Nolting" yang bertujuan untuk mendeskripsikan jenis, faktor penyebab kesalahan yang dilakukan siswa serta alternatif solusi dalam menyelesaikan soal masalah kontekstual pada materi bangun ruang sisi datar berdasarkan Teori Nolting. Manfaat dari penelitian ini adalah sebagai upaya peningkatan kemampuan siswa dalam mempelajari matematika khususnya menyelesaikan pemecahan masalah kontekstual pada materi bangun ruang sisi datar. 


\section{METODE}

Penelitian ini merupakan penelitian dengan metode deskriptif kualitatif. Metode deskriptif kualitatif dipilih sebab peneliti ingin mendeskripsikan serta menganalisis suatu kondisi atau kegiatan dengan menampilkan data apa adanya berdasarkan fakta. Tujuan penelitian ini yaitu untuk mengetahui jenis-jenis kesalahan yang dilakukan oleh siswa dalam menyelesaikan soal kontekstual pada materi bangun ruang sisi datar dan mengetahui faktor penyebab siswa melakukan kesalahan tersebut. Data yang diperoleh berasal dari subjek penelitian, yaitu siswa kelas VIII A SMP Al-Ahyar Sukaratu sebanyak 9 orang. Instrumen yang digunakan dalam penelitian ini berbentuk tes (soal) dan non tes (wawancara).

Teknik pengumpulan data berasal dari hasil jawaban tes tulis siswa dan hasil wawancara siswa. Tes tertulis dalam penelitian ini yaitu soal esai yang berjumlah 3 soal dan diberikan kepada 9 siswa yang menjadi subjek penelitian. Tes tersebut berupa soal kontekstual pada materi bangun ruang sisi datar. Tes ini digunakan untuk memperoleh data tentang jenis kesalahan siswa dalam menyelesaikan soal kontekstual pada materi bangun ruang sisi datar. Adapun kegiatan wawancara dilaksanakan untuk mendapatkan data dan informasi dari subjek penelitian, untuk mengetahui faktor-faktor yang menyebabkan siswa melakukan kesalahan dalam menyelesaikan soal kontekstual pada materi bangun ruang sisi datar. Pemilihan subjek pada proses wawancara dilakukan dengan menggunakan teknik non random (purposive sampling), yaitu hanya dipilih beberapa siswa yang paling banyak melakukan kesalahan dalam pengerjaan soal tes jika ditinjau dari Teori Nolting. Teknik tersebut diharapkan cukup memberikan gambaran yang dapat mewakili siswa secara keseluruhan dengan memiliki kriteria yang sama (Maxwell, 2005; Miles \& Hubberman, 2014).

Tabel 1. Instrumen Soal

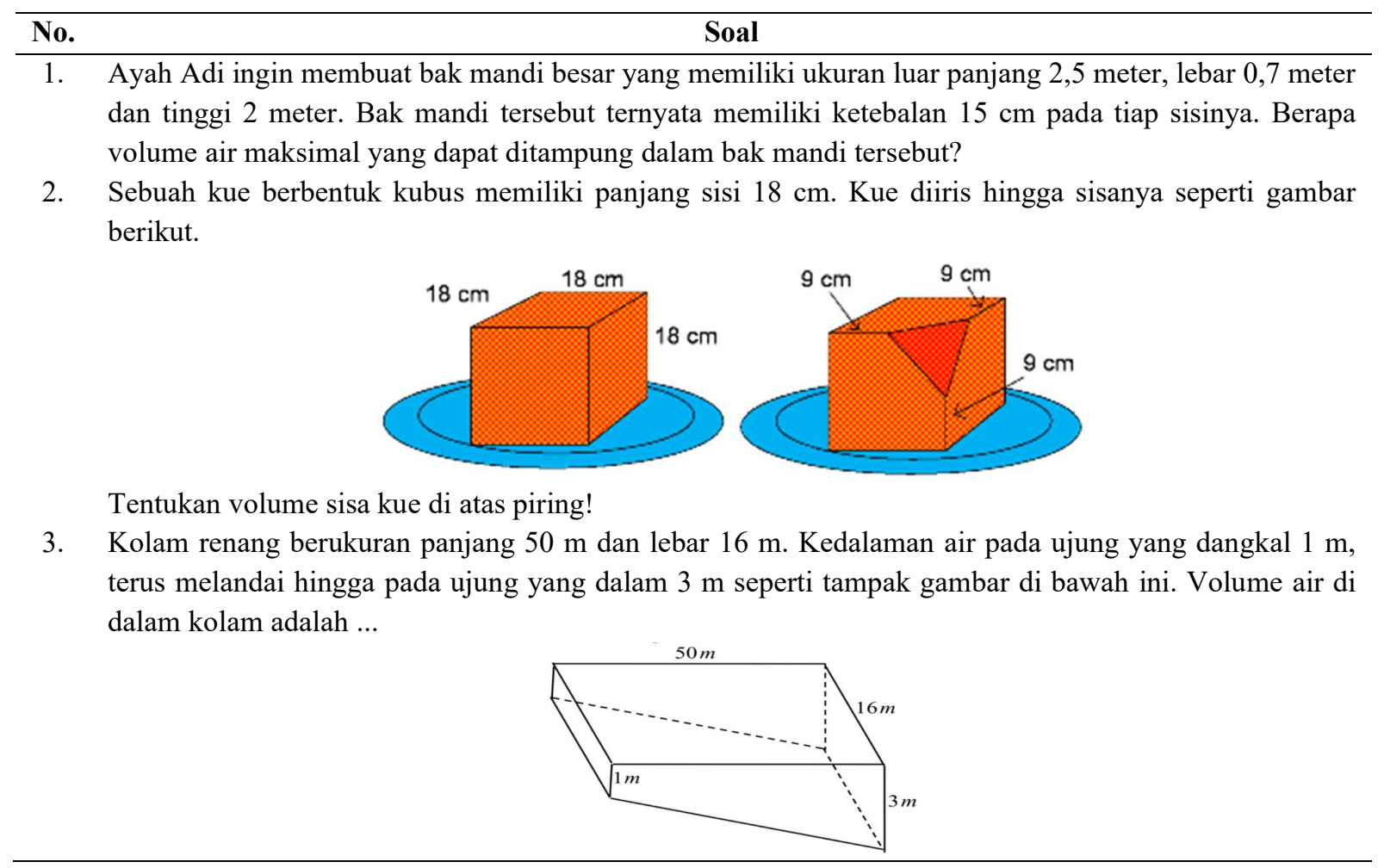


Analisis data dalam penelitian ini dilakukan secara kualitatif. Proses analisis data dilakukan setelah semua data terkumpul, yang selanjutnya disajikan dalam bentuk laporan deskriptif. Langkah-langkah analisis data yang dilakukan pada penelitian ini yaitu kondensasi data, penyajian data dan penarikan kesimpulan (Miles et al., 2014). Adapun indikator yang digunakan peneliti untuk menganalisis dan mendeskripsikan jenis-jenis kesalahan siswa dalam menyelesaikan soal kontekstual pada materi bangun ruang sisi datar, ditunjukkan pada Tabel 1 .

Tabel 2. Jenis Kesalahan

\begin{tabular}{|c|c|c|}
\hline No & Jenis Kesalahan & Indikator \\
\hline 1. & $\begin{array}{l}\text { Misread-directions } \\
\text { errors (Mi) }\end{array}$ & $\begin{array}{l}\text { - Siswa salah menafsirkan soal } \\
\text { - Siswa tidak mampu menuliskan komponen yang diketahui dan } \\
\text { ditanyakan dalam soal } \\
\text { - Siswa tidak memahami informasi pada gambar yang tertera pada soal }\end{array}$ \\
\hline 2. & Careless errors $(\mathrm{Ca})$ & $\begin{array}{l}\text { - Siswa ceroboh pada saat pengerjaan soal (salah menulis satuan, salah } \\
\text { menulis simbol, dan kurang teliti dalam operasi hitung) }\end{array}$ \\
\hline 3. & Concept errors $(\mathrm{Co})$ & $\begin{array}{l}\text { - Siswa tidak mengetahui konsep/prinsip matematika yang dibutuhkan } \\
\text { untuk pengerjaan soal (operasi hitung bilangan bulat, pecahan desimal, } \\
\text { konsep luas segitiga) } \\
\text { - Siswa tidak mengetahui sifat-sifat dan konsep bangun ruang sisi datar }\end{array}$ \\
\hline 4. & Application errors (Ap) & $\begin{array}{l}\text { - Siswa mengetahui rumus-rumus bangun ruang sisi datar namun tidak } \\
\text { dapat menerapkannya untuk pemecahan masalah pada soal }\end{array}$ \\
\hline 5. & Test taking errors $(\mathrm{Te})$ & $\begin{array}{l}\text { - Siswa membiarkan jawaban kosong tanpa menulis apa pun } \\
\text { - Siswa tidak menyelesaikan jawaban sampai akhir } \\
\text { - Siswa tidak dapat menyimpulkan hasil akhir }\end{array}$ \\
\hline 6. & Study errors $(\mathrm{St})$ & - Siswa jarang melakukan latihan soal kontekstual \\
\hline
\end{tabular}

\section{HASIL DAN PEMBAHASAN}

\subsection{Hasil}

Analisis kesalahan dilakukan oleh peneliti melalui jawaban siswa dengan berpedoman pada indikator kesalahan Nolting (Nolting, 2012), dengan mengidentifikasi jenis kesalahan mana yang dilakukan oleh siswa pada tiap soalnya. Detail bentuk kesalahan siswa dalam mengerjakan soal kontekstual materi bangun ruang sisi datar dapat dilihat pada Tabel 3.

Tabel 3. Jenis Kesalahan Siswa

\begin{tabular}{cccc}
\hline Siswa & Soal No 1 & Jenis Kesalahan & Soal No 2 \\
\hline S1 & $\mathrm{Ca}, \mathrm{Ap}, \mathrm{Te}, \mathrm{St}$ & $\mathrm{Ap}, \mathrm{Co}, \mathrm{Te}, \mathrm{St}$ & $\mathrm{Te}, \mathrm{St}$ \\
S2 & $\mathrm{Mi}, \mathrm{Ca}, \mathrm{Ap}, \mathrm{Te}, \mathrm{St}$ & $\mathrm{Mi}, \mathrm{Ca}, \mathrm{Co}, \mathrm{Ap}, \mathrm{Te}, \mathrm{St}$ & $\mathrm{Ca}, \mathrm{Te}, \mathrm{St}$ \\
S3 & - & $\mathrm{Mi}, \mathrm{Ca}, \mathrm{Te}$ & $\mathrm{Co}$ \\
S4 & $\mathrm{Mi}, \mathrm{Ap}, \mathrm{Te}, \mathrm{St}$ & $\mathrm{Mi}, \mathrm{Co}, \mathrm{Ap}, \mathrm{Te}, \mathrm{St}$ & $\mathrm{Ca}, \mathrm{Te}, \mathrm{St}$ \\
S5 & $\mathrm{Mi}, \mathrm{Te}$ & $\mathrm{Mi}$ & $\mathrm{Co}, \mathrm{Te}$ \\
S6 & $\mathrm{Ca}, \mathrm{Ap}, \mathrm{Te}, \mathrm{St}$ & $\mathrm{Mi}, \mathrm{Ca}, \mathrm{Co}, \mathrm{Ap}, \mathrm{Te}, \mathrm{St}$ & $\mathrm{Te}, \mathrm{St}$ \\
S7 & $\mathrm{Ap}, \mathrm{Te}$ & $\mathrm{Co}, \mathrm{Te}$ & $\mathrm{Te}$ \\
S8 & $\mathrm{Ca}$ & $\mathrm{Ca}, \mathrm{Co}$ & - \\
S9 & $\mathrm{Mi}, \mathrm{Ca}, \mathrm{Te}$ & $\mathrm{Mi}, \mathrm{Ca}, \mathrm{Te}$ & $\mathrm{Mi}, \mathrm{Te}$ \\
\hline
\end{tabular}


Keterangan:

Mi : Misread-Directions Errors (kesalahan membaca petunjuk )

$\mathrm{Ca}$ : Careless Errors (kesalahan kecerobohan)

Co : Concept Errors (kesalahan konsep)

Ap : Application Errors (kesalahan penerapan)

Te : Test Taking Errors (kesalahan saat tes)

St : Study Errors (kesalahan belajar)

Tabel 3 menunjukkan bahwa setiap siswa mengalami kesalahan dalam mengerjakan soal kontekstual. Persentase jenis kesalahan yang dilakukan oleh siswa dapat dilihat pada Tabel 4. Dari Tabel 4 terlihat bahwa jenis kesalahan yang dilakukan oleh kebanyakan siswa, yaitu kesalahan saat tes.

Tabel 4. Rekapitulasi Persentase Kesalahan Siswa Berdasarkan Teori Nolting

\begin{tabular}{cccccc}
\hline \multirow{2}{*}{ Jenis Kesalahan } & \multicolumn{2}{c}{ Banyak Siswa yang Melakukan Kesalahan } & \multicolumn{2}{c}{ Total } & $\begin{array}{c}\text { Persentase } \\
\text { Koal 1 }\end{array}$ \\
& Soal 2 & Soal 3 & 1 & 11 & $40,74 \%$ \\
Kesalahan & 12 & $44,44 \%$ \\
\hline Membaca Petunjuk & 4 & 6 & 2 & 8 & $29,62 \%$ \\
Kecerobohan & 5 & 5 & 2 & 10 & $37,03 \%$ \\
Konsep & - & 6 & - & 21 & $77,77 \%$ \\
Penerapan & 6 & 4 & 7 & 12 & $44,44 \%$ \\
Saat Tes & 7 & 7 & 4 & \\
Belajar & 4 & 4 &
\end{tabular}

Keterangan:

Persentase Kesalahan $=\frac{\text { Total } \text { Kesalahan }}{27} \times 100 \%$.

\subsection{Pembahasan}

Berdasarkan analisis data yang berpedoman pada Teori Nolting serta diperkuat dengan melakukan wawancara dengan 9 siswa yang bersangkutan, berikut akan dideskripsikan jenis kesalahan dan faktor penyebab siswa mengalami kesalahan tersebut.

\section{Kesalahan Membaca Petunjuk}

Persentase kesalahan membaca petunjuk adalah sebesar 40,74\%. Contoh siswa yang mengalami kesalahan membaca petunjuk adalah siswa 2 (S2). Kesalahan tersebut dapat dilihat pada Gambar 1.

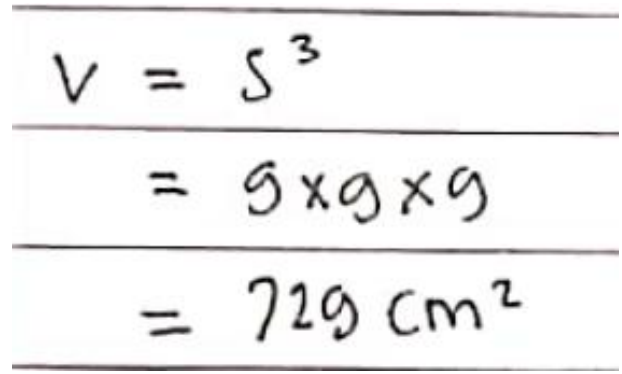

Gambar 1. Jawaban Soal Nomor 2 
Berikut adalah penggalan petikan wawancara dengan siswa 2 (S2).

$N$ : "Dek kenapa kamu tidak menuliskan diketahui dan ditanyakan terlebih dahulu?"

S2 : "Di soal kan udah jelas kak, ada gambar sama ukurannya. Saya bingung kalo diubah ke kalimat matematikanya jadi gimana. Takutnya salah, soalnya yang diketahui di soal itu rumit. Terus.. biar cepet aja gitu kak, hehe"

$N$ : "Kenapa kamu pakai rumus volume kubus dengan panjang sisi $9 \mathrm{~cm}$ ?"

S2 : (tersenyum) "Itu kan yang ditanyakan volume kue setelah dipotong ya kak. Kue nya kan berbentuk kubus, terus dipotong jadi ukurannya berubah dari $18 \mathrm{~cm}$ menjadi $9 \mathrm{~cm}$. jadi saya pake rumus volume kubus dengan sisi $9 \mathrm{~cm}$."

$N$ : "Memangnya bentuk kue setelah dipotong masih berbentuk kubus dek?"

S2 : “Iya kak, kubus tapi ada bekas potongannya juga sih kak. Saya sebenernya bingung pake rumus volume apa soalnya gak pernah nemu bangun ruang yang bentuknya kayak gitu. Jadi saya ngasal aja kak pake volume kubus, hehe."

Dari hasil tes dan wawancara di atas dapat dilihat bahwa siswa 2 (S2) melakukan kesalahan membaca petunjuk. Ia tidak menuliskan kembali informasi dalam soal dikarenakan ia tidak mampu menerjemahkan informasi pada gambar ke dalam kalimat-kalimat dan simbol matematika. Siswa 2 (S2) juga salah memahami petunjuk soal. Siswa mengatakan bahwa tidak ada jenis bangun ruang yang bentuknya seperti itu. Akhirnya ia menggunakan rumus volume kubus karena bentuknya mendekati kubus. Padahal setelah kue dipotong bentuknya tidak kubus lagi, melainkan kubus dikurangi limas segitiga. Selain itu, siswa 2 (S2) terlalu terburu-buru dalam mengerjakan soal. Sehingga ia memutuskan untuk tidak menuliskan informasi-informasi pada bagian diketahui dan ditanyakan sebelum mengerjakan soal. Karena kesalahan tersebut, akibatnya jawaban siswa menjadi tidak tepat. Hal ini sejalan dengan hasil penelitian (Fathiyah, 2020) yang menyatakan bahwa bentuk kesalahan membaca petunjuk umumnya adalah siswa hanya menuliskan jawaban akhir tanpa adanya uraian, salah menafsirkan maksud soal, tidak mampu menyebutkan komponen yang diketahui dan ditanyakan dalam soal, tidak mengetahui arti dari simbol yang ada pada soal, serta tidak mampu membaca keterangan pada gambar yang tertera dalam soal.

Berdasarkan hasil analisis tes dan wawancara dengan siswa yang mengalami kesalahan membaca petunjuk, ditemukan beberapa faktor-faktor penyebab terjadinya kesalahan tersebut, di antaranya:

a. kemampuan penalaran siswa yang rendah,

b. lemahnya kemampuan siswa dalam mengidentifikasi informasi berupa gambar ke dalam konsep matematika yang relevan,

c. kurangnya pemahaman siswa sehingga tidak mampu mengingat apa arti dari simbol yang ada pada soal, dan

d. siswa kurang memperdalam materi dan latihan soal terutama yang bersifat kontekstual. 


\section{Kesalahan Kecerobohan}

Persentase kesalahan kecerobohan adalah sebesar 44,44\%. Contoh siswa yang mengalami kesalahan kecerobohan adalah siswa 9 (S9). Kesalahan tersebut dapat dilihat pada Gambar 2.

\begin{tabular}{rl} 
Uk & $=P 250 \mathrm{~cm} \quad I=15 \mathrm{~cm}$ \\
$l \quad 70 \mathrm{~cm}$ & $L 200 \mathrm{~cm}$ \\
\hline$P$ & $=250-15-15=220$ \\
$l$ & $=70-15-15=30$ \\
$t$ & $=200-15=185$ \\
$V$ & $=220 \times 30 \times 185$ \\
& $=1221.000 \mathrm{~cm}^{3}$ \\
& $=1221$ lifer
\end{tabular}

Gambar 2. Jawaban Soal Nomor 1

Berikut adalah penggalan petikan wawancara dengan siswa 9 (S9).

$N$ : "Dek kenapa lebarnya 30?"

S9 : "Karena ini kak, 70 kan ukuran panjang luarnya terus dikurangi ketebalannya-15-15. jadi hasilnya 30."

$N$ : “Coba dicek lagi..."

S9 : "Oh iya kak, harusnya isinya 40 ya kak. Maaf kak, tadi saya ngerjainnya buru-buru, hehe"

$\cdots$

Berdasarkan hasil pengerjaan dan wawancara di atas, dapat dilihat bahwa siswa 9 (S9) melakukan kesalahan kecerobohan. Ia melakukan kesalahan dalam menghitung lebar bak mandi. Kesalahan tersebut bukan karena ia belum paham mengenai operasi pengurangan. Namun dikarenakan terlalu tergesa-gesa dalam mengerjakan soal sehingga ia tidak teliti dan tidak mengecek kembali jawabannya. Akibatnya hasil akhir dari jawabannya menjadi tidak tepat. Kesalahan yang sama juga diungkapkan oleh Swan (Faturrochmah et al., 2021) yaitu kesalahan manusia dapat dilihat dari berbagai alasan, karena kurangnya konsentrasi, pemikiran yang terburu-buru, memori yang penuh atau kegagalan mencatat hal yang penting ketika belajar.

Berdasarkan hasil analisis tes dan wawancara dengan siswa yang mengalami kesalahan kecerobohan, ditemukan beberapa faktor-faktor penyebab terjadinya kesalahan tersebut, di antaranya:

a. siswa terlalu tergesa-gesa dan tidak teliti dalam mengerjakan soal,

b. siswa tidak mengecek kembali jawaban sebelum diserahkan ke peneliti, dan

c. siswa tidak fokus ketika mengerjakan soal dikarenakan suara bising di rumah. 


\section{Kesalahan Konsep}

Persentase kesalahan konsep adalah sebesar 29,62\%. Kebanyakan siswa sudah mumpuni terhadap materi prasyarat yang digunakan untuk pengerjaan soal. Meski begitu, sebagian kecil siswa masih ada yang mengalami kesalahan konsep dalam pengerjaan soal. Contoh siswa yang mengalami kesalahan konsep adalah siswa 3 (S3). Kesalahan tersebut dapat dilihat pada Gambar 3.

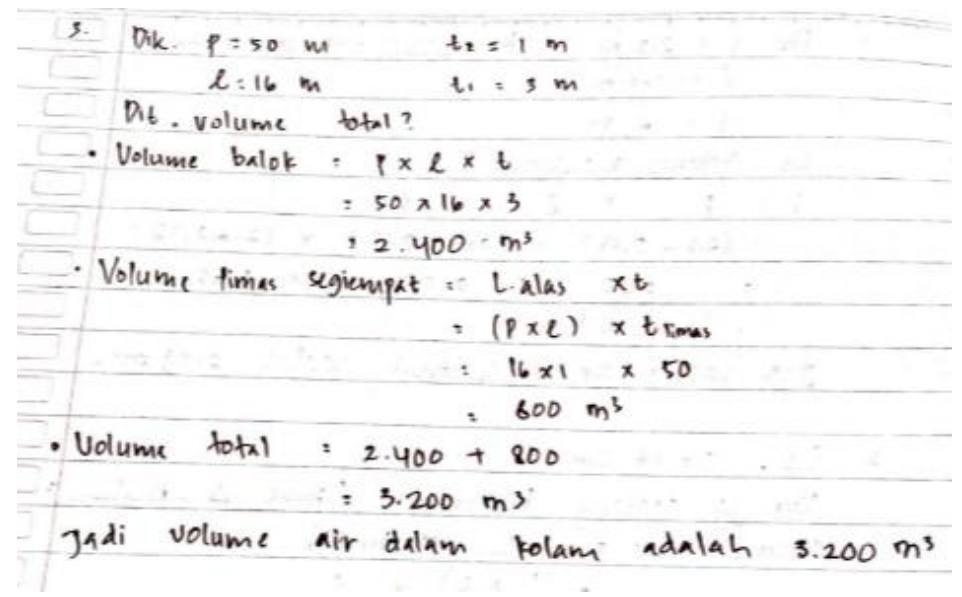

Gambar 3. Jawaban Soal Nomor 3

Berikut adalah penggalan petikan wawancara dengan siswa 3 (S3).

$\cdots$

$N$ : "Jawaban no 3 ini kenapa pake rumus ini dek?"

S3 : "Aku ngebayanginya kolam ini bentuk balok kak, terus selebihnya bentuk limas segiempat”(menunjuk gambar)

$N$ : "Coba dicek lagi dek, apakah betul kolam itu bentuknya gabungan dari balok dan limas segiempat?"

S3 : "Sepertinya sudah betul kak, eh tapi... bingung kak, hehe"

$N$ : "Bukannya limas itu harus ada titik puncaknya ya dek? Kalau disana titik puncaknya yang mana?"

S3 : "Ini kak" (sambil menunjukkan)

$N$ : "Lho itu kan bukan titik, tapi garis"

S3 : "Oh iya... (terdiam sejenak). Sepertinya gak ada titik puncaknya kak, hehe”

Berdasarkan hasil pengerjaan dan wawancara di atas, dapat dilihat bahwa siswa 3 (S3) melakukan kesalahan konsep. Ia mengira bahwa bentuk kolam merupakan gabungan dari bangun ruang balok dan limas segi empat. Ia belum paham betul sifat-sifat bangun ruang limas. Sehingga ia salah dalam menggunakan rumus yang mengakibatkan jawaban akhirnya menjadi salah pula. Sejalan dengan hasil penelitian (Oktafia \& Sutama, 2019) yang menyatakan bahwa kesalahan konsep disebabkan siswa salah menggunakan rumus dalam menjawab permasalahan yang disajikan dalam soal serta penggunaan rumus yang tidak sesuai dengan kondisi atau prasyarat berlakunya rumus tersebut.

Berdasarkan hasil analisis tes dan wawancara dengan siswa yang mengalami kesalahan konsep ditemukan beberapa faktor-faktor penyebab terjadinya kesalahan tersebut, di antaranya: 
a. kurangnya pemahaman yang mendalam pada konsep dan sifat masing-masing jenis bangun ruang sisi datar dan

b. rendahnya kecerdasan visual-spasial (kemampuan untuk menangkap dunia ruang-visual secara tepat).

\section{Kesalahan Penerapan}

Persentase kesalahan penerapan adalah sebesar 37,03\%. Contoh siswa yang mengalami kesalahan penerapan adalah siswa 2 (S2). Kesalahan tersebut dapat dilihat pada Gambar 4.

3 Diketahui :
$\quad p=50 \mathrm{ml}=16 \mathrm{ma}=1 \mathrm{mb}=3 \mathrm{~m}$
Ditanyakan $=v ?$
$v=1 / 2 \times(a+b) \times p \times 1 \mathrm{~V}=1 / 2 \times(1+3) \times 50 \times 16 \mathrm{~V}$
$=1 / 2 \times 4 \times 800 \mathrm{~V}$
$=1.600 \mathrm{~m}^{3}$

Gambar 4. Jawaban Soal Nomor 3

Berikut adalah penggalan petikan wawancara dengan siswa 2 (S2).

$\cdots$

$N$ : "Kenapa ini ada v nya dek? 16v terus 800v?"

S2 : "Oh itu dari rumusnya kak. Itu kan pake rumus volume prisma trapesium $v=\frac{1}{2} \times(a+b) \times p \times l v$ lalu disubstitusi"

$N$ : "lv itu apa dek?"

S2 : "Sepertinya l itu lebar tapi v nya saya juga bingung, hehe."

$\cdots$

Berdasarkan hasil pengerjaan dan wawancara di atas, dapat dilihat bahwa siswa 2 (S2) melakukan kesalahan penerapan. Siswa terbilang tahu rumus yang digunakan untuk menyelesaikan soal tersebut. Namun, ia hanya tahu saja. Ia tidak paham betul arti dari simbolsimbol pada rumus itu sendiri. Sehingga ia tahu rumus namun tidak dapat menerapkannya untuk mengerjakan soal-soal. Darmawati (Sukmawati \& Amelia, 2020) menyatakan bahwa siswa hanya menuliskan komponen yang diketahui dan rumus yang digunakan, tetapi siswa mengalami kesulitan dalam menjawab soal.

Berdasarkan hasil analisis tes dan wawancara dengan siswa yang mengalami kesalahan penerapan, ditemukan beberapa faktor-faktor penyebab terjadinya kesalahan tersebut, di antaranya:

a. siswa hanya menghafal rumus tanpa mengetahui maksud dan arti dari simbol-simbol yang ada pada rumus itu sendiri,

b. kurangnya latihan soal yang seharusnya dapat membantu siswa dalam meningkatkan kemampuan menerapkan konsep dan rumus yang dipelajari ke dalam soal, dan 
c. siswa hanya mengandalkan LKS sebagai sumber belajar. Penjelasan LKS begitu ringkas dan contoh soalnya pun terbatas. Sehingga siswa kurang bisa menerapkan rumus untuk pengerjaan soal.

\section{Kesalahan Saat Tes}

Persentase kesalahan saat tes adalah sebesar $77,77 \%$. Contoh siswa yang mengalami kesalahan saat tes adalah siswa 6 (S6). Kesalahan tersebut dapat dilihat pada Gambar 5.

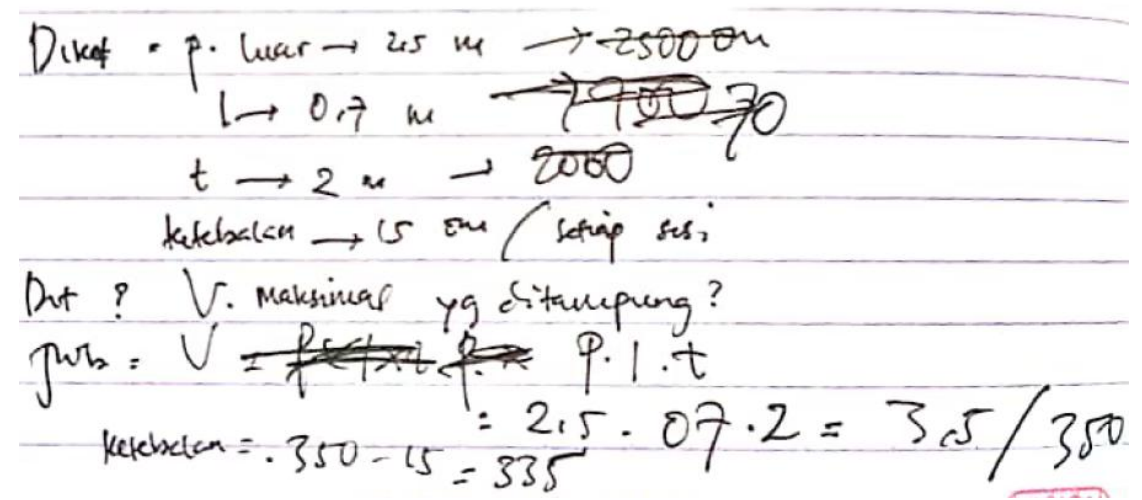

Gambar 5. Jawaban Soal Nomor 1

Berikut adalah penggalan petikan wawancara dengan siswa 6 (S6).

$N$ : "Maksud jawaban kamu ini gimana dek?"

S6 : "Di soal kan ditanya volume maksimum bak mandi, nah berarti kan pake rumus volume balok $v=p \times l \times t$. Tapi kan itu ada ketebalan jadi dari volume itu dikurangi ketebalan"

$N$ : "Kenapa kamu tidak menuliskan kesimpulan jawabannya dek?"

S6 : "Saya mau nulis tapi saya ragu sama jawaban saya kak. Karena kalau dipikir-pikir kayaknya ketebalan itu bukan dikurangi tapi dibagi, hehe"

$\cdots$

Berdasarkan hasil analisis jawaban dan wawancara di atas, dapat dilihat bahwa siswa 6 (S6) melakukan kesalahan saat tes. Siswa tidak mampu menunjukkan jawaban akhir dengan kalimat kesimpulan. Hal ini sejalan dengan Puspita (Faturrochmah et al., 2021) yang menyatakan bahwa peserta didik melakukan kesalahan dengan tidak menuliskan kesimpulan ataupun menuliskan kesimpulan namun salah.

Berdasarkan hasil analisis tes dan wawancara dengan siswa yang mengalami kesalahan saat tes, ditemukan beberapa faktor-faktor penyebab terjadinya kesalahan tersebut, di antaranya:

a. siswa tidak terbiasa menuliskan jawaban akhir dengan kalimat kesimpulan,

b. siswa lupa tidak mengakhiri jawaban dengan kalimat kesimpulan,

c. siswa merasa ragu terhadap jawabannya sendiri sehingga tidak berani menyampaikan kesimpulan dari jawabannya, dan

d. siswa kurang mampu mengatur waktu dalam mengerjakan soal sehingga tidak dapat menyelesaikan pekerjaannya. 


\section{Kesalahan Belajar}

Persentase kesalahan belajar adalah sebesar 44,44\%. Jenis kesalahan ini diperoleh dari hasil analisis terhadap hasil tes dan wawancara dengan 9 orang siswa yang bersangkutan. Contoh siswa yang mengalami kesalahan belajar adalah siswa 4 (S4). Berikut penggalan petikan wawancara dengan siswa 4 (S4).

$$
\begin{aligned}
& N \text { : "Kenapa jawaban kamu salah semua dek?" } \\
& \text { S4 : "Soalnya susah-susah kak. Aku gak biasa ngerjain soal yang bentuknya }
\end{aligned}
$$

...

Dari penggalan petikan wawancara di atas, menunjukkan bahwa siswa 4 (S4) mengalami kesalahan belajar. Kesalahan tersebut, yakni ia tidak sering melakukan latihan soal terhadap soal-soal yang sifatnya kontekstual. Sehingga ketika ia mendapatkan soal matematika kontekstual ia kesulitan untuk menentukan permasalahan apa yang disajikan dan bagaimana cara menyelesaikannya. Sejalan dengan hasil penelitian Ariyadi Wijaya (Wati \& Murtiyasa, 2016) bahwa siswa Indonesia sebagian besar memiliki kesulitan dalam memahami soal berbasis konteks.

Selain melakukan wawancara dengan siswa 4 (S4), peneliti juga mewawancarai 8 siswa lainnya. Pertanyaan yang diajukan seputar kebiasaan siswa ketika belajar. Berdasarkan hasil wawancara tersebut ditemukan faktor-faktor penyebab terjadinya kesalahan tersebut, di antaranya:

a. siswa jarang mengerjakan latihan soal, terutama yang bersifat kontekstual,

b. siswa lebih menekankan hafalan rumus daripada pemahaman konsep, dan

c. siswa kurang memperdalam materi, ia hanya mengandalkan satu sumber yang terbatas untuk menunjang pembelajaran.

Dari pemaparan deskripsi jenis kesalahan dan faktor penyebab siswa mengalami kesalahan di atas, peneliti menawarkan beberapa solusi untuk mengatasi hal tersebut, di antaranya adalah sebagai berikut.

a. Solusi untuk meminimalkan kesalahan membaca petunjuk (misread-directions errors), yaitu sebaiknya siswa lebih berhati-hati dalam membaca soal, pahami apa saja informasi yang akan ditulis dalam poin diketahui dan ditanyakan, serta sering mengerjakan latihan soal berupa permasalahan kontekstual untuk meningkatkan kemampuan penalaran.

b. Solusi untuk meminimalkan kesalahan kecerobohan (careless errors), yaitu tidak terlalu terburu-buru ketika mengerjakan soal, memeriksa kembali jawaban sebelum dikumpulkan, jika memungkinkan hitung kembali hasil pengerjaan.

c. Solusi untuk meminimalkan kesalahan konsep (concept errors), yaitu menuntaskan pemahaman konsep dan contoh soal terlebih dahulu sebelum mengerjakan soal tes, bertanya kepada guru jikalau menemukan konsep yang sulit dipahami, mempelajari 
terlebih dahulu materi prasyarat yang belum dikuasai, serta memastikan bahwa konsep matematika yang dipahami sudah benar.

d. Solusi untuk meminimalkan kesalahan penerapan (application errors), yaitu siswa membiasakan diri mengerjakan latihan soal dengan berbagai jenis dan level. Sehingga konsep dan rumus yang sudah dipelajari bisa diterapkan untuk mengerjakan soal tes yang diberikan.

e. Solusi untuk meminimalkan kesalahan saat tes (test taking errors), yaitu membiasakan diri mengakhiri jawaban dengan kalimat kesimpulan, tidak terpaku pada 1 soal, kerjakan soal dari yang termudah ke tersulit,

f. Solusi untuk meminimalkan kesalahan belajar (study errors), yaitu sering melakukan latihan soal terutama yang sifatnya kontekstual, memahami dan menggali konsep dari materi yang diajarkan di samping menghafal rumusnya, serta mempelajari materi dari berbagai sumber terpercaya.

\section{SIMPULAN}

Berdasarkan hasil penelitian dan pembahasan, dapat disimpulkan bahwa terdapat 6 jenisjenis kesalahan siswa dalam menyelesaikan soal kontekstual materi bangun ruang sisi datar berdasarkan Teori Nolting. Pertama, kesalahan membaca petunjuk sebesar 40,74\%, faktor penyebabnya yaitu rendahnya kemampuan penalaran siswa. Kedua, kesalahan kecerobohan sebesar 44,44\%, faktor penyebabnya yaitu dalam mengerjakan soal, siswa terlalu tergesa-gesa. Ketiga, kesalahan konsep sebesar 29,62\%, faktor penyebabnya yaitu siswa kurang pemahaman dan memperdalam konsep bangun ruang sisi datar. Keempat, kesalahan penerapan sebesar $37,03 \%$, faktor penyebabnya yaitu siswa hanya menghafal rumus tanpa mengetahui maksud simbol dan arti dalam rumus tersebut. Kelima, kesalahan saat tes sebesar 77,77\%, faktor penyebabnya yaitu siswa tidak terbiasa menulis kesimpulan. Keenam, kesalahan belajar sebesar $44,44 \%$, faktor penyebabnya yaitu siswa jarang mengerjakan latihan soal bersifat kontekstual.

\section{DAFTAR PUSTAKA}

Fajriyati Afdila, N., Roza, Y., \& Maimunnah. (2018). Analisis Kesalahan Siswa dalam Menyelesaikan Masalah Kontekstual Materi Bangun Ruang Sisi Datar Berdasarkan Tahapan Kastolan. Jurnal LEMMA, 5(1), 65-72. https://doi.org/10.22202/j1.2018.v5i1.3383

Fathiyah, I. (2020). Analisis Kualitatif Kesalahan Pengerjaan Soal Matematika Tipe HOTS Berdasarkan Teori Nolting Pada Siswa SMP. http://repository.upi.edu

Faturrochmah, H., Sary, R. M., \& Azizah, M. (2021). Kesalahan Siswa dalam Mengerjakan Soal Materi Bangun Ruang Datar Berdasarkan Teori Nolting Pada Siswa Kelas IV Sekolah Dasar. Elementary School: Jurnal Pendidikan Dan Pembelajaran Ke-SD-An, 8(2), 310-321. https://doi.org/10.31316/ESJURNAL.V8I2.1404

Fazzilah, E., Effendi, K. N. S., \& Marlina, R. (2020). Analisis Kesalahan Siswa dalam Menyelesaikan Soal Pisa Konten Uncertainty dan Data. Jurnal Cendekia: Jurnal Pendidikan Matematika, 4(2), 1034-1043. https://doi.org/10.31004/cendekia.v4i2.306 
Hasibuan, E. K. (2018). Analisis Kesulitan Belajar Matematika Siswa pada Pokok Bahasan Bangun Ruang Sisi Datar di SMP Negeri 12 Bandung. AXIOM : Jurnal Pendidikan Dan Matematika, 7(1), 18-30. https://doi.org/10.30821/axiom.v7i1.1766

Miles, M. B., \& Hubberman, A. M. (2014). Qualitative Data Analysis (2nd. ed). Thousand Oaks: Sage Publications.

Miles, M. B., Hubberman, A. M., \& Saldana, J. (2014). Qualitative Data Analysis: A Methods Sourcebook (3rd. ed). In California : SAGE Publications.

Napfiah, S., \& Sulistyorini, Y. (2021). Errors analysis in Understanding Transformation Geometry through Concept Mapping. Internatinal Journal of Research in Education, $1(1), 6-15$.

Nolting, P. D. (2012). Math Study Skills Workbook: Your Guide to Reducing Text Anxiety and Improving Study Strategies.

Oktafia, R., \& Sutama, M. (2019). Analisis Kesalahan Dalam Menyelesaikan Soal Geometri Berorientasi Pisa Ditinjau Dari Gender Pada Siswa Kelas VIII Smp Muhammadiyah 2 Masaran. http://eprints.ums.ac.id/id/eprint/79127

Prihatin, D., \& Setiawan, W. (2020). Analisis Kesalahan Siswa SMP Kelas IX dalam Menyelesaikan Soal pada Materi Pokok Bangun Ruang Sisi Datar. MAJU (Jurnal Ilmiah Pendidikan Matematika), 7(1), 63-69. https://www.ejournal.stkipbbm.ac.id/index.php/mtk/article/view/427

Sukmawati, S., \& Amelia, R. (2020). Analisis Kesalahan Siswa SMP dalam Menyelesaikan Soal Materi Segiempat Berdasarkan Teori Nolting. Jurnal Pembelajaran Matematika Inovatif, 3(2), 223. https://doi.org/10.22460/jpmi.v3i5.423-432

Wati, E. H., \& Murtiyasa, B. (2016). Kesalahan Siswa SMP dalam Menyelesaikan Soal Matematika Berbasis PISA pada Konten Change and Relationship. Konferensi Nasional Penelitian Matematika Dan Pembelajarannya (KNPMP I), Knpmp I, 199-209. 